\title{
Efforts to Preserve Macapat by Mantradisi Art Group in Yogyakarta
}

\author{
Brigitta Puspa Juwita ${ }^{1 *}$, Kusnadi $^{2 * *}$ \\ Graduate School, Yogyakarta State University, Yogyakarta, Indonesia \\ *Corresponding author,Email: brigittapuspa@ymail.com, \\ **Corresponding author, Email: kusnadi@uny.ac.id
}

\begin{abstract}
This study aims to find out and describe efforts to preserve the Macapat art by the Mantradisi group, and know the benefits experienced by the Mantradisi group after the group was formed. This qualitative research used a phenomenological approach and there were two sources of data, namely primary and secondary data sources. The data analysis techniques comprised data reduction, data display, and conclusions drawing and the data were validated through a technical triangulation. The results show that to preserve Macapat art, the Mantradisi group combined traditional and modern art. This is a social action based on rational circumstances classified into instrumental rationality because the group has been able to determine the strategy to achieve a certain goal. Furthermore, the benefits are categorized into two aspects, namely economic and social aspects. Keywords: preservation efforts, Macapat, phenomenology
\end{abstract}

\section{INTRODUCTION}

Art is one of the results of conscious human efforts made to become the character or icon of the society in each region. Indonesia, as a multicultural country, is very rich in a variety of customs and arts spread from Sabang to Merauke. Art might be form from a tradition or culture that grows and develops in each region. Therefore, art and culture are two inseparable things interrelated with one another. Sometimes people as cultural owners forget their duties and responsibilities to preserve their culture, and this causes the existence of some traditional arts as a form of cultural heritage in a quite alarming status. The main factor that often causes this problem to occur is the lack of interest of young generations to perpetuate these traditional arts.

One form of traditional art that is quite well known in the Java region is Macapat. At present, Macapat has possibly been less desirable and has less selling value. Macapat is a Javanese literary work in the form of poetry which is played by singing so that it is often referred to as a song in Javanese. Although the art of Macapat is a song, it is not the same as other Javanese songs. What distinguishes Macapat songs from other songs is the attachment of not have a permanent poem, meaning that artists can change their poems, but they still have to follow the conventions or metrum of each type of Macapat they want to create. The eleven types of Macapat songs widely recognized by the general public are believed to have a series of sequences with a philosophy describing the journey of human life. These eleven sequences of the Macapat song are Mijil, Kinanthi, Sinom, Asmarandana, Dhandhanggula, Gambuh, Masumambang, Durma, Pangkur, Megatruh, and Pocung [1].
Macapat songs to certain conventions. Macapat as a traditional Javanese poem has 3 conventions in the making of its poetry, which includes guru gatra (number of lines per stanza), guru wilangan (number of syllables per line), and guru lagu (sound of the last syllables in the line) [1]. These conventions are said to be challenges in the composing novel Macapat songs, so it is not surprising that the traditional arts have been increasingly abandoned.

Macapat songs, as a noble cultural heritage, have a variety of values that are really meaningful. These poems gives a lot of advice for everyone to live in society. Therefore, other than as an expression of the taste of the artists, Macapat songs are often used as media for delivering positive advice. At present, people are only more familiar with 11 types of Macapat, whereas according to the findings of the Behrend Team from the University of Auckland there are approximately 71 types of songs found based on their metrum [2]. The term Metrum itself is usually used as a literary language that refers to conventions existing in Macapat songs as differentiating features of Macapat songs from other songs. Each type of Macapat songs does Besides, each Macapat song also has its characteristics described by the Wacana Nusantara Team as follows. Mijil is defined as moved and impressed; Kinanthi has the unified, happy, affectionate character; Sinom is pleased, joyful, and alluring; Asmarandana is melancholy, longing, and tender-hearted; Dhandhanggula is sweet, flexible, and charming; Gambuh is sensible, clear, without hesitation; Maskumambang character is grim, sad, touched, miserable, and full of pain; Durma is passionate, hard, and grumpy; Pangkur is strong-bodied, gallant, passionate, enthusiastic; 
Megatruh is sorrowful, sad, full of pain, disappointed, and wistful; Pocung has a relaxed, subjective character, as in Balabak; Girisa is cautious and serious; Jurudemung is pleased, joyful, and alluring; and Wirangrong is defined as authoritative [3].

Regarding its alarming status, there have been a few people who still intend to save this traditional art. This effort should be appreciated as the performers of traditional arts, although just in a relatively small number, have at least made an effort to help the next generations not to lose this valuable cultural heritage. One of the art groups that take part in the preservation of Macapat in Yogyakarta is Mantradisi. The group consists of several young people from Yogyakarta, so that the existence of this group can be one of the proofs of preservation efforts that have been initiated by the community, especially the younger generations.

These efforts have certainly been done as a conscious act based on encouragement or motivation; likewise, those carried out by Mantradisi. The formation of the group was not without any reason, or of course, there was motivation, encouragement, and a strong desire from its members, especially the founder.

Regarding this, human conscious actions in the preservation efforts can be classified as social acts. Parson, in his theory of action, enlightens that actors behave to achieve a particular goal. Their actions are influenced by a variety of facts, namely the availability of tools, inhibiting conditions, prevailing norms, and the cultural system in which these actors live [4]. Weber states that his thoughts on social changes that occur in society are very closely related to the development of rationality dominant in humans. He groups rationality into four types, namely the first is traditional rationality which is a form of rationality to fight for values already existing in the traditions of the society; the second is affective rationality, a type of rationality closely related to emotions and feelings; the third is value-oriented rationality in which the community sees value as the goal of life even though the goal is not real in daily life; and the fourth, instrumental rationality where the community has been able to determine the tools (instruments) used for achieving a particular goal [5].

In this research, the theory of social action will be used to dissect the intentions and objectives of Mantradisi in carrying out efforts to preserve the art of Macapat. The theory of social action used is focused on the theory of social action based on rational circumstances because it sees that the action taken by the group is a conscious act carried out rationally. Wallace and Wolf state that theories based on rational choice assume that people are intelligent and base their actions on what they consider to be the most effective way to achieve their goals [6]. While in other enlightenment given by George C. Homans in Kinseng, one's actions are the result of a calculation between values and the likelihood of success of those actions [4]. Thus, rational work is carried out in the presence of more or less thought as follows. An individual operation is carried out so that the percentage of the level of success achieved is much higher, or in other words, the activity is carried out to minimize something that can reduce the level of success, so that the rational action closely related to the existence of several considerations that have been thoroughly considered.
Besides, efforts to preserve Macapat by Mantradisi amidst the decline of the Macapat art's existence currently make scholars interested in conducting further studies. In addition to knowing its conservation efforts, researchers also expect to find out more about the benefits received by group members. Thus, the formulation of the problem in this study is divided into two as follows. (1) How is the preservation of Macapat art carried out by Mantradisi? (2) What are the benefits received by group members, especially the founder of the group, after forming the group? Following the formulation of the problem, the purpose of this study includes to describe the efforts to preserve Macapat by the Mantradisi and find out the benefits of the group members.

\section{RESEARCH METHOD}

This is qualitative research with a phenomenological approach. This approach was employed as the researchers intend to interpret, study, and understand the reasons for the artists or informants in choosing an action as an effort to preserve Macapat, which was adjusted to the original purpose of the research, which is to describe the effort to protect Macapat and describe the benefits received by Mantradisi group members. According to Collin, phenomenology seeks to understand informants about phenomena that arise where it is considered as an entity that exists in the world [7]. This is in line with Christensen, Johnson, and Turner in Simon and Goes, that the primary purpose of a phenomenological study is to explain the meaning, structure, and essence of the life experience of someone or a group of people about certain phenomena [8]. In short, phenomenologists try to understand human behavior through the eyes of participants in the research.

The research subjects were members of the Mantradisi group. Data sources were divided into two, namely primary data sources derived from interviews, and secondary data sources obtained from observation and documentation. Data were then analyzed by data reduction, data presentation, and drawing conclusions. While the data validity test uses triangulation techniques, namely cross-validating the interview data and the results of observation and documentation.

\section{RESULTS AND DISCUSSION}

\section{A. Macapat Art Preservation Efforts}

The use of conventions or often referred to as "standard" in the Macapat song causes Javanese artists or poets to be less interested in this art because it feels less free to compose compared to other Javanese literature. The lack of interest of artists in preserving Macapat was possibly one of the factors that encourage Mantradisi to focus on taking part in efforts to preserve it.

In these efforts, Mantradisi innovates their ways by combining traditional and modern art. Traditional art comes from Macapat art itself and the use of some conventional musical instruments such as Gamelan, while contemporary art comes from the use of several modern musical instruments such as Western ones. However, aside 
from using Western musical instruments in general, including guitars and drumsets, Mantradisi also add modern types of electrophone instruments including iRig keys, midi controller, and synthesizer; also using Macbook software including garage band and logic pro; as well as several sound effects including SFX vocals, SFX bass, and SFX guitars. The use of these tools is to create a variety of sound effects that cannot be produced only with conventional musical instruments. With the use of these tools in the accompaniment of the Macapat song, the nuances of the Macapat presentation of the Mantradisi group slightly differ from that of the original ones. This is one mode Mantradisi does in reviving the art of Macapat in order to regain its existence in the society currently inferior to other types of Javanese literature or songs with Javanese language lyrics.

The collaboration between traditional and modern art has been based on certain aims and objectives. Aside from being a preservation effort, the use of modern art in the Macapat songs presented by Mantradisi is used to increase the selling value of the Macapat song itself, so that this traditional art can better guarantee the lives of its artists. At present traditional arts such as original Macapat song art when used as a show are considered to have very low selling value. It seems to be different if Macapat is packaged into a more modern show. The use of more upto-date lighting, stage, and the sound system, improving publications in the social media, and exclusively the use of modern musical instruments are considered to increase its selling value because these contribute in producing professionally managed paid traditional art performances. Mantradisi stressed that the innovations still keep the conventions or "standards" existing in the original Macapat's Metrum consisted of guru wilangan, guru gatra, and guru lagu. The Macapat artworks created by Mantradisi never changed the standard rules, even some of the characteristics of the Macapat song are still preserved. However, sometimes some words originated from foreign languages are often included in their works. The foreign languages include languages other than Javanese, for example, Indonesian, Malay, or Arabic. One of the Arabic uses of Mantradisi is in an array of lines in the form of takbir inserted into one of the Pangkur Macapat song verses with the title of "Selarong" as follows.

mingkar-mingkuring mataram
kethuk tinabuh siaga prajurit
wadyabala samya kumpul
mawa cara gerilya
selarong gamplong kedu pajang madiun
allah akbar allah akbar
prang sabil lawan walandi

The above Pangkur Macapat song has the metrum of 7 (8a, $11 \mathrm{i}, 8 \mathrm{u}, 7 \mathrm{a}, 12 \mathrm{u}, 8 \mathrm{a}, 8 \mathrm{i})$. The number 7 at the beginning of the meter shows the convention of the guru gatra which means there are 7 lines in each of the Macapat song. While the numbers $8,11,8,7,12,8,8$ sequentially refer to the number of syllables in each array, this convention refers to as a guru wilangan. Lastly, the letters a, i, u, a, u, a, i sequentially refer to the sound of the last syllable in each line, which is referred to as the guru tembang. It can be seen, in this stanza, the sixth line reads "Allah is great
Allah is great", the sentence is a sentence of takbir in Arabic, which proves the existence of foreign languages in the Mantradisi's Macapat song. The use of the foreign languages does not necessarily change the rules that exist in the original Macapat because Macapat is in the serat (Javanese literary works containing ancestral teachings such as the Centhini which also has included foreign languages.

As for what is done by Mantradisi still raises the pros and cons of the public, especially those who still hold fast or thick the rules of tradition, by often mentioning that what is done by Mantradisi has damaged the original Macapat art. However, the main objective of the preservation of Mantradisi is to embellish it so that it can be more accepted by the public, especially the younger generations, without intending to damage its original artistic features. With the existence of more modern innovations, it is expected that the young age groups will start to be interested again in cultivating traditional arts which they often consider to be an old thing that is difficult to enjoy. Therefore, the target audience of the Mantradisi group is young people who are the same age as the members of the Mantradisi group, and also millennials who possibly have the same tastes as what is presented by Mantradisi. The group invites the audiences to be able to return to enjoy one of the Javanese traditional arts in a performance that suits what they want, which is a more modern nuance and not merely ancient.

These efforts can also be termed a social action based on rational circumstances since there exist specific goals and objectives. In achieving their goals, Mantradisi has been able to determine the right way, namely by making an innovation, from the original Macapat to the combination of traditional and modern art. Thus, the rational actions taken by Mantradisi can be classified into instrumental rationality. Based on one theory of rational actions that have been mentioned in the introduction, according to Homans in Tuner (1998), a person's actions are the result of a calculation between values and the likelihood of success of those actions [4], so the Mantradisi must have calculated what they do. Such a calculation is more or less as follows. If Mantradisi innovates the original Macapat art, their success in preserving the Macapat art can be reaccepted in the community, especially the younger generations, and also their success in raising the selling value of the Macapat art will be much likely higher. Even though they are in the mission of preserving traditional arts, they are also trying to change the traditional arts which were previously considered less able to support their artists to be of higher selling value and can be one of the professions and a promising source of income.

\section{B. The Benefits of Macapat Preserving Efforts}

The Macapat art preservation efforts carried out by the Mantradisi group brought several benefits felt by its members. One of the perceived benefits can be seen from the economic aspect. Mantradisi has provided additional income for its members for every show they perform. In addition to the financial point, other benefits come from the social issue where one of the members of the Mantradisi group who at the same time as the founder of the group is often involved in various cultural preservation 
events and other activities dealing with traditions such as seminars on cultural preservation, Javanese script training program, editing a culture magazine, and being appointed as one of the coordinators of an annual arts festival in Yogyakarta Municipality. The benefits seen from this social aspect have opened up the life of the founder of the Mantradisi group and raised its name to one of the great artists in Yogyakarta. This advantage also gave him many responsibilities in the missions of preserving Javanese culture.

\section{Conclusions}

Based on the findings described above, then in this study, it can be concluded that in the efforts to preserve Macapat art, one of the methods used by Mantradisi is to combine traditional and modern art. Modern art discussed includes the use of musical instruments and other more up-to-date performance equipment. Efforts to preserve Macapat by Mantradisi constitute social actions based on the rational state because of its specific aims and objectives. These rational actions are classified as instrumental acts of rationality because Mantradisi has been able to determine how to achieve these goals. Some of the benefits of conservation efforts felt by group members are divided into two aspects, namely economic and social. From the financial aspect, it can be seen that the Macapat art performance made by Mantradisi has become one of the additional income sources for group members even though they are on a cultural preservation mission. As for the social aspect, in addition to being seen from the popularity of group members among Yogyakarta artists, it is apparent from several offers received by one of the group members, especially the founder of the Mantradisi group, who has been actively involved in various cultural events.

\section{REFERENCES}

[1] Gumilang, Galang Surya. "Internalization of Philosophical Value "Tembang Macapat" in Guidance and Counseling." Prosiding Seminar Nasional Bimbingan dan Konseling. Vol. 1. No. 1. 2017.

[2] Tim Behrend. List of Metres in Javanese Texts. University of Auckland, unpublished.

[3] Mulyono, Mulyono, and Asmaun Sahlan. "Pengaruh Islam Terhadap Perkembangan Budaya Jawa: Tembang Macapat [The Influence of Islam on the Development of Javanese Culture: Macapat Song]." el-Harakah 12.1 (2012): 101-114.

[4] Kinseng, Rilus A. "Structugency: A Theory of Action." Sodality: Jurnal Sosiologi Pedesaan 5.2 (2017).

[5] Martono, Nanang. Sosiologi Perubahan Sosial: Perspektif Klasik, Modern, Posmodern, dan Poskolonial [The Sociology of Social Change: Classical, Modern, Postmodern, and Postcolonial Perspectives] (Sampel halaman). Raja Grafindo Persada Jakarta, 2012.
[6] Wallace, Ruth A., and Alison Wolf. Contemporary Sociological Theory. Expanding the Classical Tradition (Sixth Edition), Pearson, Prentice-Hall, New Jersey, 2006.

[7] Collin, Finn. Social Reality. USA and Canada: Routledge Simultaneously Published, (1997).

[8] Simon, Marilyn K., and Jim Goes. "What Is Phenomenological Research". (2011). URL: http://dissertationrecipes.com/wpcontent/uploads/2011/04/PhenomenologicalResearch.pdf 